This is an electronic reprint of the original article. This reprint may differ from the original in pagination and typographic detail.

Author(s): Szerovay, Mihaly; Itkonen, Hannu; Vehmas, Hanna-Mari

Title: 'Glocal' processes in peripheral football countries : a figurational sociological comparison of Finland and Hungary

Year: $\quad 2017$

Version:

Please cite the original version:

Szerovay, M., Itkonen, H., \& Vehmas, H.-M. (2017). 'Glocal' processes in peripheral football countries : a figurational sociological comparison of Finland and Hungary. Soccer and Society, 18(4), 497-515.

https://doi.org/10.1080/14660970.2015.1067785

All material supplied via JYX is protected by copyright and other intellectual property rights, and duplication or sale of all or part of any of the repository collections is not permitted, except that material may be duplicated by you for your research use or educational purposes in electronic or print form. You must obtain permission for any other use. Electronic or print copies may not be offered, whether for sale or otherwise to anyone who is not an authorised user. 


\section{'Glocal' processes in peripheral football countries: A figurational sociological comparison of Finland and Hungary}

The aim of this article is to increase the understanding of the global and local contexts in football by finding out what social, cultural and economic dimensions seem to characterize 'periphery' football. This study applies figurational sociological perspective, which is applicable to the research on globalization processes and sport. The sources utilized are publications on the history and sociology of football as well as interviews with football practitioners. First, a theoretical framework of the global football figuration is advanced. Second, applying the constructed framework, the concept of periphery football country is discussed. It was found in accordance with previous research that instead of the rigid conceptualization of peripheral football, the various developmental patterns of countries should be studied. Third, the diverse development paths of Finnish and Hungarian football are analysed and compared. It is suggested that in spite of being peripheral, both countries have been increasingly integrated into the global football figuration.

Keywords: periphery football; figurational sociology; glocalization; Finland; Hungary 


\section{Introduction}

Football has undergone profound changes in both sociocultural and economic terms to which its interactions with globalization processes have greatly contributed. By the 21 st century, football unquestionably forms a part of the global entertainment industry and the commercial popular culture. Furthermore, it is the primary sport in the majority of the countries in the world. It is reasonable to say that globalization and football are heavily intertwined.

Globalization is a complex historical process whose relevant driving force is the varying interdependencies between the local and the global. ${ }^{1}$ Ever-changing global sport figurations have evolved, which challenge both scholars and sport practitioners on the local level to get a better understanding of these phenomena and engender benefits for societies via sport. Global sport figurations "are shaped and contoured by a range of global flows, particularly of people, technology, capital, mediated images and ideologies". ${ }^{2}$ The concept of figuration also points to the networks of interdependencies that connect, enable and constrain the functioning of people. ${ }^{3}$

\section{Scarce Research on Peripheral Countries of Football}

Social science, in general, and the field of global studies, in particular, have disregarded the relevance of football to globalization processes. ${ }^{4}$ The majority of research to date on football and globalization has focused on core football countries, ${ }^{5}$ such as Spain, Germany and England, which have a strong and high-quality football culture with significant income from corporate partners and media companies.

However, far too little attention has been paid to the countries and clubs that are located in the periphery of the international football. Studies on peripheral football include 'Fringe Nations in World Soccer' by Bandyopadhyay and Mallick, the special 
issues of Soccer \& Society journal on peripheral countries in 2011 and on Scandinavian countries in $2009 .{ }^{6}$ In the context of Finland and Hungary, there is hardly any academic studies focusing on the recent social, cultural and economic effects of globalization on sport, ${ }^{7}$ though some research has been carried out on Finnish and Hungarian football and globalization by Itkonen, Nevala, Heinonen as well as Krausz, Szabados, Molnar and Juhasz, respectively. ${ }^{8}$ The present article attempts to address these hitherto ignored perspectives within the topic area of globalization and football.

\section{Research questions}

The main aim of this article is to increase the understanding of the global and local axes of the football domain. More specifically, this paper aims at finding out what complex and interdependent social, cultural and economic dimensions seem to characterize 'peripheral' football. The paper adopts a figurational or process-sociological approach and the concept of the 'duality of glocality'. 9

First, the global football figuration will be discussed by identifying the actors as well as the interdependencies and power relations between them. This will be achieved by giving an overview of the economic, social and cultural dimensions of the recent changes in football. This will set the scene for carrying out the second and third research tasks: to discuss the concept of peripheral football and assess Finland and Hungary's situation within the figuration. The paper addresses the following research questions:

(1) What characterizes the global football figuration?

(2) In what way can periphery countries be defined in the football context?

(3) Why can Finland and Hungary be considered as periphery football countries? 
The research materials used in this article are formed by semi-structured interviews conducted with five Finnish and two Hungarian football practitioners as well as publications on the history and sociology of international, Finnish and Hungarian football. Contrary to international research on football, Finnish and Hungarian research traditions are considerably scarce.

\section{The global football figuration}

The figurational sociology approach is employed given that it is applicable for discussing the evolution of professional sports, the relations between globalization processes and sport and the global sport formation. ${ }^{10}$ According to this concept, social figurations cannot be separated from the people who compose them with each other. ${ }^{11}$ These individuals and societies form processes within global figurations, where power is a function of interdependency ties. The processes evolving this way appear as the intended and unintended consequences of the accumulation of intended individual actions. ${ }^{12}$ Furthermore, these figurations extend over time and space and are characterized by tension balances. ${ }^{13}$ As a result, complex networks of interdependencies are created.

Figurations need to be the basic entities to be examined when one researches sport. ${ }^{14}$ Using this approach also permits to "emphasize the multifaceted, multidirectional and complex sets of power balances that characterise the global sport process" ${ }^{15}$ In practice, it involves the interconnected groups related to a sport club such as owners, players, fans, sponsors, sport organizations, mass media, and the government. ${ }^{16}$

However, figurational sociology pioneered by Norbert Elias has been often criticized for its lack of distinctiveness and originality. For example, Bauman argued that there is an obvious link between the idea of figuration and other ordinary concepts 
such as pattern and situation. ${ }^{17}$ In fact the term figuration was chosen by Elias according to its linguistic properties. ${ }^{18}$ He referred to the figuration of humans and this way aimed at avoiding the tension between structure and agency. ${ }^{19}$

\section{Duality of glocality}

In order to better comprehend the global-local axis of the global football figuration, it is reasonable to add the concept of 'duality of glocality' coined by Giulianotti and Robertson. According to this concept, processes of convergence and divergence or homogenization and heterogenization occur simultaneously in cultures. ${ }^{20}$ Instead of being substitutes of each other, they develop together, thus creating 'commonly diverse' cultures. ${ }^{21}$ There is a dynamic interchange going on between the local, national and the global, which may include emulation, resistance or reinvention of certain sporting forms. ${ }^{22}$ For instance, football in Africa has been used both as a tool for the Westerndriven cultural imperialism and for the resistance to imperial intentions. ${ }^{23}$ Local and national experiences and interdependencies can be better captured by locating them within global flows. In conjunction with the duality of glocality, for process sociology, "the explanatory frame of reference must be global in perspective". ${ }^{24}$ As an illustration, Darby points out that the evolution and development of FIFA (International Federation of Association Football) cannot be understood without the consideration of wider global processes. ${ }^{25}$ Dunning also argues that the restructuring of football should be contemplated within the framework of the processes of globalization and Europeanization. $^{26}$

The key elements of the figurational approach that are employed throughout this paper are the focus on the complex and multi-layered development paths of football by examining the changing power balances as a function of interdependency ties between the different actors involved. In addition homogenization and heterogenization 
processes of glocalization will be identified, which enable a more profound understanding of periphery football countries.

\section{Economic transformations in professional football}

Professional football clubs have been transformed into companies and started to operate by the rules of the market economy over the course of the last decades. Football companies produce spectator sport services, which form a trinity of interdependence with the market and the media. ${ }^{27}$ Clubs have become capitalist entities and increasingly focus on profit maximization ahead of utility maximization. ${ }^{28}$

These transformations can be tightly connected to the worldwide expansion of the highly controversial neoliberalist policies. Professional clubs have been surrounded by a wide range of stakeholders and at the same time a variety of investment methods appeared in football business. Within this figuration, international bodies such as the UEFA (Union of European Football Associations) and the FIFA, as well as the media have considerable financial power. In addition, club owners have sufficient power to make critical decisions. ${ }^{29}$ Not surprisingly, fans are the least powerful members of the figuration. ${ }^{30}$ The balances of power between these actors shifted considerably in recent years $^{31}$ and keep changing continuously.

As a consequence, clubs' incomes have soared from television rights and corporate partners, especially in the so-called core countries of football. ${ }^{32}$ Based on Lechner's definition, core countries comprise wealthy, industrialized countries. ${ }^{33}$ On the same token, core country of football refers to one with strong club and national teams, with the ability of dominating the global football market and football tournaments.

The processes of globalization have also contributed to the negative outcomes in reference to football, such as inequalities of wealth between countries, ${ }^{34}$ as well as clubs, ${ }^{35}$ betting scandals that have undermined football's reputation in various countries 
and rising costs of attending games. ${ }^{36}$ The economic recession of the late 2000 s has considerably affected the sport sector as well. Although football clubs' incomes have increased to a great extent, so have the expenditures, which have caused several clubs accruing considerable losses year after year.

\section{The social and cultural dimensions of the global football figuration}

Professional football clubs have been active participants of a growing network of social relationships, including various stakeholders of the clubs as well as media and other domestic and foreign teams. These relationships are marked by interdependency ties formed by power relations. ${ }^{37}$ Clubs have been increasingly connected, both locally and globally. ${ }^{38}$ The concept of 'connectivity' discloses the social 'electricity' of global processes. ${ }^{39}$ For example, partly as a consequence of the liberalization of the player market, player migration has sped up producing multicultural team squads over the past decades. For instance, the increase in the number of foreign players in the Finnish Premier League and Finnish players in other leagues underpins the effect of globalization in Finland. ${ }^{40}$ Although globalization increasingly facilitates player mobility, their routes depend highly on what kind of environment they come from. ${ }^{41}$ Furthermore, connectivity contributes to disconnectivity, which means that certain societies are unable to establish many reference points with global flows. ${ }^{42}$ An example may be the relative disconnectivity of Eastern European clubs in international tournaments. This phenomenon can also be called 'peripheral inclusion' to international football. $^{43}$

From a cultural point of view, the "football/globalization nexus is a highly varied one in which multipolar influences are at play". ${ }^{44}$ The concept of 'glocalization' has been developed and defined in many distinct ways since the 1980s. Recently glocalization has also been explained with the concepts of 'duality of glocality' by 
Giulianotti and Robertson and 'diminishing contrasts and increasing varieties' by Maguire. It should be noted that homogenization mainly appears at the structuralinstitutional level while heterogenization at the expressive-symbolic level. ${ }^{45}$ By way of illustration, homogenization in football suggests that it is played by universal rules in the whole world, with a central governance of FIFA. Heterogenization implies that countries have distinctive playing styles and fan cultures. Further themes that permit the analysis of 'duality of glocality' with reference to convergence and divergence in football include referee styles, media interpretation, along with club governance and club finance. ${ }^{46}$

After considering the changes in the football domain and synthesizing Clark's, Dunning's, and Bourke's ideas on the global sport formation as well as Giulianotti and Robertson's view on glocalisation, ${ }^{47}$ the following figure is advanced to demonstrate the range of actors and processes of the global football figuration.

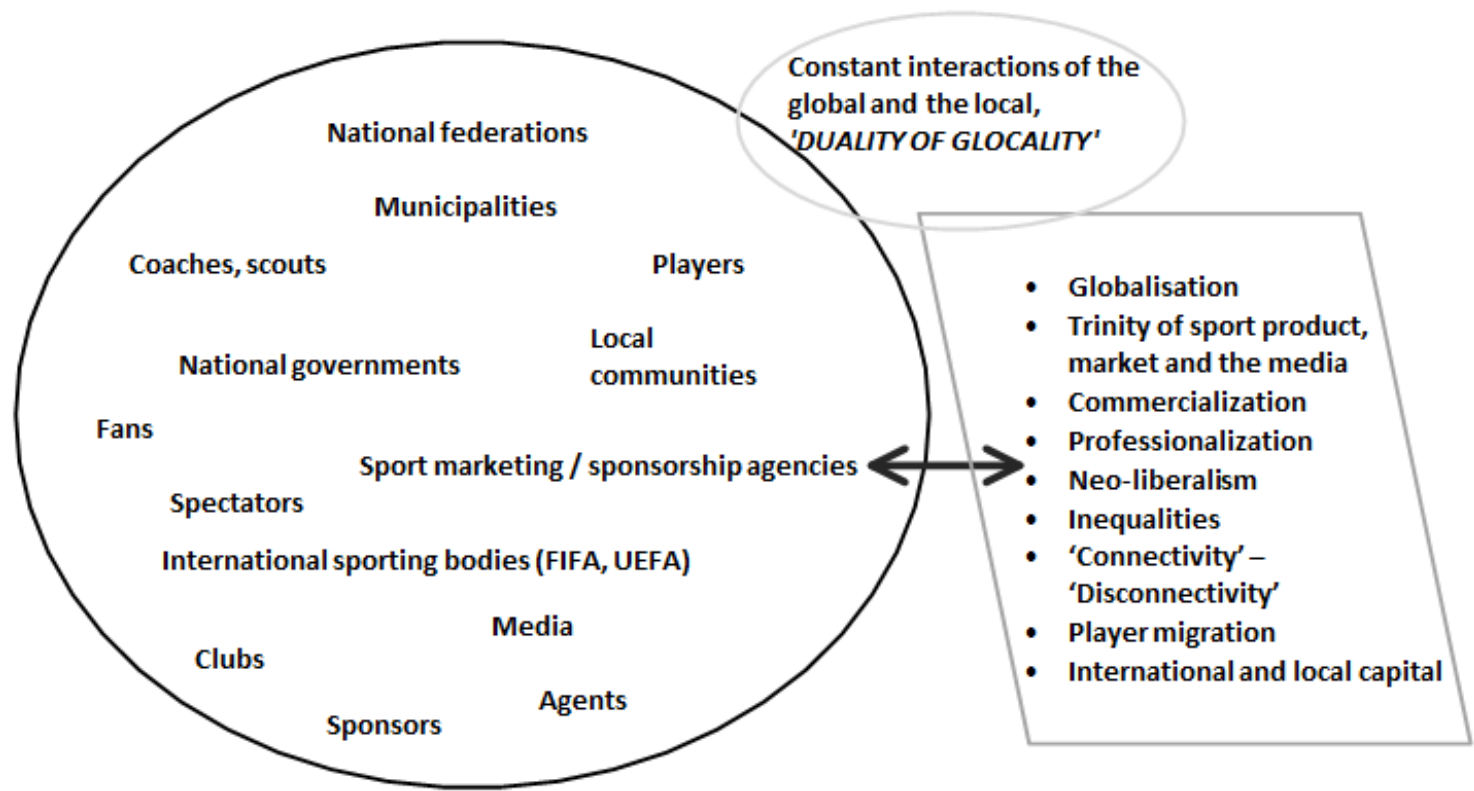

Figure 1. Actors and processes in the global football figuration. 
The actors and the processes in this figuration cannot be separated from each other, given that the actors are part of the processes. This conceptual framework is believed to assist in understanding the situation of periphery football countries.

\section{Peripheral football}

\section{The categorization of peripheral football}

Periphery countries "have marginal roles in the world economy and are dependent on 'core' countries in their trading relationships". ${ }^{48}$ By the same token, periphery countries of football could be understood as football countries that have relatively underdeveloped football culture and minor role in world football. Peripheral areas of football are the greater parts of Asia and Africa, the Australian continent, some parts of Europe and Latin America and North America. ${ }^{49}$

The figurational perspective focuses on the analysis of social processes. It is not only historical, but rather developmental processes that should be concentrated on. In this context, it means that different sports have their own developmental paths and directions, of which meanings can only be discovered via detailed empirical studies of the changes. ${ }^{50}$

Many of the theoretical approaches that may be linked to the concept of periphery countries and globalization of football traditions have a rather economic offset, given that the principal driving force triggering globalization is economic. ${ }^{51}$ Therefore the economic dimension, especially the market economy is inevitable for the understanding of this matter. ${ }^{52}$ Nevertheless, it can be argued that the economic determinism represented for instance by Marxist sociology limits their input in explaining the long-term development of sports. ${ }^{53}$ Maguire confirms that it is not enough to analyse economic differences between countries or areas. ${ }^{54}$ 
Wallerstein's world system theory from the field of political economy from 1974 deals with the "historical dynamics of capitalism". ${ }^{55}$ This theory identifies core, periphery and semi-periphery nations taking the economic dimension as an offset between countries. Wallerstein predicates that core countries exploit and impoverish the peripheral countries using their economic power. ${ }^{56}$ Although Wallerstein's theory has some significant arguments with respect to this study, it does not fit into the figurational framework proposed because it presents the core-periphery relationship as unidirectional with the intention of core countries imposed on the periphery. Dependency theory, applying an economic standpoint, advocates core, semi-periphery and periphery distribution as well, ${ }^{57}$ but it features global inequalities in a more dynamic and diffuse way compared to the world system theory. ${ }^{58}$ Maguire also suggests the nations within the global sports figuration to be divided into core, semi-peripheral and peripheral groups. He proposes a multi-causal and multi-directional figurational approach and adds the political and cultural dimensions to the discussion. ${ }^{59}$

Other observations about the core-periphery debate related to categorization of core, semi-peripheral and peripheral frameworks vary from sport to sport and are thus complicated to interpret to football. The sporting dimensions of the concepts of core and periphery do not always correspond to their economic or other dimensions. Some core nations such as Japan, USA and Finland have (semi-)periphery football cultures. ${ }^{60}$ Sport success, which may be an indicator of a country's belonging to either core, semiperipheral or peripheral groups, depends on several factors. ${ }^{61}$ Experience, population and income per capita of certain countries play a vital role in explaining success in football. ${ }^{62}$ Lamprech and Stamm conclude that domestic economy and traditions are the decisive factors. ${ }^{63}$ Experience and traditions may be measured for example by the 
amount of internationals played by a country. These measurements are mainly quantitative, and therefore lack a more in-depth cultural and social analysis.

Periphery-core definitions may also refer to players and clubs instead of countries. For instance, Lanfranchi and Taylor structured European football as group A, core, B, semi-periphery and C, periphery. ${ }^{64}$ Considering professional football, Pierpoint differentiates A-list clubs, 'UEFA-chasers' and 'survivors' within the English Premier League. ${ }^{65}$ Pierpoint's categories are reflected by the annual turnover, operating profits, players' salaries and supporter bases of each club. Furthermore, the periphery is present in the core by the players playing in clubs in core countries. It is also reasonable to say that countries have their own periphery. ${ }^{66}$ In the case of Finland, for instance, football's core areas are often Finnish baseball's periphery and vice versa, what implies a power struggle between these two sports.

\section{The 'development' process of periphery football countries}

Bandyopadhyay \& Mallick call nations on the periphery of football fringe nations. ${ }^{67}$ They argue that "the historical roots and growth, cultural adoption and appropriation, and developmental patterns and potentials of the game" in fringe countries of football vary greatly and make any homogenization impossible. ${ }^{68}$ Therefore, the idea of marginalized or less developed football nations cannot be strictly conceptualized.

The division between core, semi-periphery and periphery may be understood that as a result of globalization, some countries are marginalized to the benefit of the core. ${ }^{69}$ Clubs from the core countries of football, notably England, Germany, Spain, France, Italy and the Netherlands, with the help of multinational capital, monopolize the football players' and consumer markets that are built upon football. ${ }^{70}$ In addition, homogenization theories explain how convergence arguments concerning for example mass communications emerged, ${ }^{71}$ such as the mainly one-directional communication 
flow from the core to the periphery countries. A good example of this is the broadcasting of the English Premier League in numerous countries.

However, a multi-casual multidirectional approach proposed by figurational sociologist should be applied that can interpret both homogenization and heterogenization processes when examining these issues. ${ }^{72}$ For instance, these core countries have been at least partly 'peripherized' themselves through the arrival of players from developing countries. ${ }^{73}$ Nevertheless, despite the multi-directional dependencies, these processes are characterized by a core-periphery perspective. ${ }^{74}$

Although peripheral countries of football may be identified, it should be noted that greater interdependence exists between the global and the local that need to be analysed. ${ }^{75}$ Therefore, being a peripheral football country is not a static state, but rather constant and dynamic shifts of power. ${ }^{76}$ It is about a 'development' process of the constantly changing football figuration. Furthermore, it is also suggested that the strict conceptualization of periphery nations is rather complicated. Each country has its own periphery; inside the locality, there are "all sorts of independencies, rivalries, power struggles and conflicts". ${ }^{77}$

\section{Finland and Hungary on the periphery of the football domain}

Finland and Hungary are relatively small countries with a population of 5,4 million and 10 million, respectively. According to the World Bank, Finland's GDP per capita (based on purchasing power parity) for the $2010-2014$ period is 38,251 US dollars per year and the same data for Hungary is $22,878,{ }^{78}$ which means that Finland may be considered as a core and Hungary as a semi-periphery country economically. Finland has never qualified to any football World Cups or European Championships. Hungary has a noteworthy football tradition with two second places in the World Cups and three gold medals at the Olympics; however, a decline started in the 1980s and the national team 
has not reached a major tournament since 1986.

With regards to the present, a CIES (Centre International d'Etude du Sport) Football Observatory research on the economic level of European football leagues divides the 31 leagues included in the investigation into 4 groups based on the average budget for personnel expenses. ${ }^{79}$ According to the results, both the Finnish and Hungarian leagues belong to the lowest category, which means less than three million euros per year are spent on player budget. Moreover, as reported by UEFA's website, the country coefficient ranking for the $2014 / 15$ season is $31^{\text {st }}$ for Hungary and $36^{\text {th }}$ for Finland out of the 54 UEFA member countries. These rankings are formed according to the performance of each association's clubs in the five past UEFA Champions League and Europa League seasons. The position of these countries in the men's World Ranking according to FIFA's website is $50^{\text {th }}$ and $63^{\text {rd }}$, respectively, as of 12 November 2014. The numeric data presented suggest that Finland and Hungary are peripheral football countries when considering sport performance. However, as it was proposed above, the concept and categorization of peripheral football is fairly complex and varies considerably by countries; there is a need to look behind the numbers to examine the political-economic, social and cultural dimensions of the development processes and answer the questions 'why?' and 'how?'.

\section{Finland and Hungary within the global football figuration}

\section{The economic and political dimensions of the development of Finnish and}

\section{Hungarian football}

The strong civil society characterized by an active and influential third sector in Finland has impeded the development of a market-oriented environment for sport. The direction of progress based on amateur principles was underpinned by a decision of the Finnish 
football association favouring amateur football in the $1920 \mathrm{~s} .{ }^{80}$ In addition, the agricultural economic structure, less urban society and poor facilities hindered the development of professional football in Finland as well. ${ }^{81}$ Furthermore, there has been a centre-periphery division characterized by the fault lines between bigger towns and rural areas. ${ }^{82}$

The market started to gradually gain a more important role in the sport environment from the 1970s. The sport culture has differentiated, which means that new forms of sport have become more popular, the division of labour within sport clubs have become necessary and clubs of one discipline have evolved. Thus clubs started to need more resources, which made the involvement of the market essential. At the same time market actors began to demand publicity. Consequently, a trinity of market - media sport product characterized by interdependencies has developed.

Although the league system was established in 1989, marking the era of differentiation in sports, no considerable football business has evolved in Finland. ${ }^{83}$ Even today, the highest level of division of football, called Veikkausliiga, is rather a semi-professional league. One of the informants, Lassi Hietanen, chairman of the first division football club JJK Jyväskylä, points out that "if you want to run a professional club in Finland, you need at least one million euros from year to year". The budgets of 5 out of 12 football clubs in the Veikkausliiga were under one million euro in $2012 .{ }^{84}$ Nonetheless, the status of first league players can be observed applying the typology of sport professionalism by Dunning. ${ }^{85}$ It is an overt, legitimate type of professionalism, in which income is acquired from commercial actors as well as gate receipts. The proportion of the commercial revenue is extremely high in the case of Finnish Veikkausliiga clubs, as it can reach as much as $80 \%$ of the annual budget, ${ }^{86}$ which implies a risky business model and vulnerability for clubs. 
Hungary has had a fairly different economic and political environment with a state socialist system from 1949 to 1989 , in which top-level sport was financed centrally and its autonomy was heavily limited. Consequently, sport clubs economic activity was limited and mainly concentrated on managing the money they had. ${ }^{87}$ By way of illustration, Ferencvarosi TC was backed by the ministry of agriculture and Budapest Honvéd by the National army. Under state socialism, the private sector was totally absent. The typology of sport professionalism by Dunning can be applied here as well to unfold the status of athletes in that era. ${ }^{88}$ It denoted a covert, non-legitimate type of sports professionalism, when a formally amateur athlete had a state supported job. After 1989 an occupation in player career has converted to an overt, legitimate type of professionalism.

The communist system was by its very nature centralized and favoured the centre to the periphery, what reflected the weight of clubs from the capital in the national league. ${ }^{89}$ During the so-called consolidation after the 1956 revolution a slow increase in the autonomy of football became more evident. It reflected the intention of the power centre to shift towards a state-controlled 'consumer socialism'.${ }^{90}$ In the 1980s, compared to the 1960s and 1970s, power relations shifted from the centre in favour of local institutions with financial, political and administrative resources. ${ }^{91} \mathrm{With}$ the slow decrease of football's political significance, the state imparted less resources to clubs and therefore football's decline has started.

After the political and economic transition in Hungary in 1989-90, the development of sport moved towards pursing the patterns of the Western countries. ${ }^{92}$ The country opened its markets in the beginning of the 1990s. At the same time the state stopped supporting football, which in a country without capital caused the downfall of sport. ${ }^{93}$ With the transition towards the free-market economy a 'vacuum' was formed, 
characterized by the lack of information, professional knowledge, organization and primarily money. ${ }^{94}$ Football became a sport product that had to be sold, but sport leaders did not have the experience. The national league lost its best players for unreasonably small amounts of money and players of poorer quality came from abroad. This example of 'brawn-drain' demonstrates the core-periphery nature of interdependencies in the football figuration.

Sport is still subject to political manipulation in Hungary, although it is presented in more subtle ways. An evidence of this is the distorted characteristics of sport sponsorships with 'second agenda', which are not based on real market logics, as in the case of Hungarian first league team Videoton FC. ${ }^{95}$ In addition, broadcasting rights for the 2012-2016 seasons were bought by the Hungarian national publicbroadcasting company for higher than the real market price, what may also be considered as a hidden state support for football clubs, argues Gabor Szabados, a notable Hungarian sport economist. These examples underpin the arguments that in peripheral countries, the mixture of Western and local ways evolved. It can be assumed that "the interaction of the local and the global resulted in a hybrid formation of organizing the sport market". ${ }^{96}$ For the time being, it seems that neither the centralistic nor the market-based approach can be an absolute base for a well-functioning Hungarian football. ${ }^{97}$ Copying the Western football models cannot work due to the lack of capital and different societal background. ${ }^{98}$

\section{Football in the Finnish and Hungarian sport cultures}

Football in Finland has always been a sport of the cities and urban areas; its diffusion to the countryside was relatively slow. ${ }^{99}$ This is tightly related to the fact that football has fought for a life space with other sports, but especially with Finnish baseball, which was then considered a national defence sport and that assisted the spread of the sport to the 
rural areas. It is still the most popular summer sport in some smaller towns and rural areas. ${ }^{100}$ By way of illustration, Finnish baseball grew popular in a town called Varkaus, located in Eastern Finland, in the 1960s following the success of local teams. This caused football losing spectators as well as the best players; football's position weakened considerably in that power struggle. ${ }^{101}$

Football competitions were moderate in the beginning of the 1900s; the first league system was not organized until the 1930s. ${ }^{102}$ Moreover, the situation of the Finnish players has been quite challenging due to harsh weather conditions. ${ }^{103}$ It has directly affected the development of football by reducing the amount of time for practice per season. Even today, officials from numerous football clubs complain about the winter conditions and they confirm that it is a considerable drawback for Finnish players compared to countries that have the facilities to practice all year round. Although football is the most practiced sport measured by the number of licenced amateurs, it can be argued that the wide basis of players on the grassroots levels has not been transformed to success internationally or to clear increase in attendances. ${ }^{104}$

Sport in Finland has traditionally been based on volunteerism, which has also affected the development of football in manifold ways. Partly due to the lack of professionalism, Finland experienced a dearth of success in football and a peripheral position in the global football figuration; this contributed to the fact that Finland belongs to those countries that have gone through modernization and nation building processes without any significant addition from football. When it comes to Finnish fan culture, it is typical that fans support the national team with excitement, but they do not value club football that much. Moreover, a huge number of fans support foreign clubs, especially English ones, which is in accordance with fans' opinion that Finnish football being on the periphery of international football. ${ }^{105}$ 
Contrary to Finland, sport in Hungary has not been self-organized and lacked strong civil society. In spite of that, football, being the number one sport of the country, has been a substantial component of socio-historical processes and social identity. ${ }^{106}$ During the state socialism, sport was considered as fulfilling public interest through the success it achieved. "The communist regime tried to deprive the teams of their earlier semantic contents, material bases, and often, of their fans". ${ }^{107}$ The political system used football "to symbolize their cultural and societal equality or superiority to Western cultures"108 and utilized it as a tool for legitimacy. However, at the same time it worked as a form of national resistance against the ruling system as well, for instance at Hungarian-Soviet matches, ${ }^{109}$ and following the football World Cup final which concluded with a defeat against West Germany in 1954, which resulted in a disturbance by disappointed fans. ${ }^{110}$

During the years of post-communist transition, Hungarians experienced ideological and economic confusion, which could be understood as the "transition period from Sovietization to Europeanization". ${ }^{111}$ Hungarians were used to an acceptable standard of living with moderate effort during the 1980s, particularly compared to the neighbouring state socialist countries. As Szabados interprets it, the socalled "soft dictatorship produced soft people", which may explain in part the present situation in football. It may take a long time to change the practices. At the same time, unstable social and football environment was created, primarily due to the lack of proactive behaviour of the Hungarian football clubs and the regional, economic, political and social circumstances. ${ }^{112}$ The function of sport has changed in various ways as well. For instance, the expression of national pride was not confined to sports anymore. ${ }^{113}$ The social distance between professional athletes and ordinary people has grown. Civil 
society in Hungary does not have sufficient personal and financial resources.

Furthermore, the spirit of volunteerism has not yet diffused into the society. ${ }^{114}$

\section{The social dimensions of the development of Finnish and Hungarian football}

Although Finland took part in international tournaments as early as at the 1912 Stockholm Olympics and the first players who became professionals moved abroad in the 1950s, Finland has been connected to the international football culture tighter and thus has become a more active member of the global football figuration since the 1970s. ${ }^{115}$ The country has integrated in international football especially via international games at all levels as well as via player transfers and can be considered as a transit country for players. ${ }^{116}$ Nowadays, there are a considerable amount of players from Eastern Europe in the Veikkausliiga and over 70 Finnish players in around 20 countries. ${ }^{117}$ Nevertheless, Lassi Hietanen, chairman of football club JJK Jyväskylä, suggests some teams aim at having almost exclusively home-grown players on their squad, which, apart from a financial concern, may be a form of resistance to increasing player migration.

Together with other Eastern European countries being part of the Soviet bloc, Hungary had a restricted role within the global football figuration before 1990. Although based on the performance of the national and club teams, it could clearly be considered a core country; connections to the West were strictly controlled. Players and coaches were not allowed to move abroad. ${ }^{118}$ Those who defected from the country were considered enemies of the system and were not allowed to return to Hungary. However, compared to ordinary citizens, top players had privileged situations due to travelling abroad to play international games with the Hungarian national or club teams. A way of acquiring social mobility was to become an exceptional athlete. ${ }^{119}$ Nonetheless, a number of players and coaches fled Hungary, searching for better living 
standards in Western Europe. These emigrants contributed to the spread of then advanced Hungarian style of playing football. Regulations and attitudes related to player migration got looser in the 1980s, which was also manifested by the return of one of the greatest football players ever and former Hungarian 'Golden team' captain, Ferenc Puskas over 20 years in Spain, after he left Hungary two years after the Hungarian Revolution in 1958. Similar to the Finnish Veikkausliiga, nowadays the Hungarian league is mainly seen as a stepping stone to stronger leagues. ${ }^{120}$

Table 1 summarizes the changes discussed above in the football domain of Finland and Hungary since the 1950s. These points indicate the situation of these countries within the global football figuration.

Table 1. Changes in Finnish and Hungarian football environments since the 1950s.

Finland Hungary

ECONOMIC AND POLITICAL DIMENSIONS

Agricultural economy $\ddagger$ highly industrialized mixed economy

Democratic country with civil actor nature of sport based on volunteerism

Towards market-oriented sport

Amateur football $\ddagger$ overt, legitimate type of sport professionalism and semi-professionalism

Division between the bourgeois and working class sport organizations $¥$ reduced role of politics No significant sport business
Planned economy $\ddagger$ market economy

Nowadays democratic, former state socialist country with state supported sport lacking strong civil society

Towards market-oriented sport

Covert non-legitimate type of sports professionalism $\ddagger$ overt, legitimate type of sport professionalism

Football as a tool of legitimation of the political system $\ddagger$ politics is still present in football No significant sport business

\section{CULTURAL DIMENSIONS}

Football has not been the No 1 spectator sport / Football is the most popular amateur team sport Football has been the No 1 sport both in terms of spectators and participants

Football has been significant component of sociohistorical processes and social identity formation

Periphery football country

\section{SOCIAL DIMENSIONS}

Transit country / Supplier in the football market

Peripheral inclusion in the global football figuration

Restricted mobility of players $¥$ Supplier in the football market

Peripheral inclusion in the global football figuration 
The outcomes of this article reinforce the idea that figurations need to be the basic entities when researching sport, given that the development of football can be understood only when they are examined within the context of the interconnected groups they exist in and considering power relations within the figurations. Football clubs' interdependency with the political power in Hungary and football's power struggle with Finnish baseball in Finland are primary examples of these power relations. This article has also pointed out the applicability of the concept of the duality of glocality to the development of Finnish and Hungarian football. On the one hand, clubs becoming companies, augmenting player mobility, and the increasingly market-oriented environment of football with the employment of professional and semi-professional players, and the involvement of commercial partners are good examples of homogenization processes. On the other hand, football's different social meanings and political significances confirm heterogenizaton processes. These homogenization and heterogenization processes are intertwined; by way of illustration, the political dimension of Hungarian football influences the sponsorship activities and the market of broadcasting rights.

Finnish and Hungarian football have been characterized by diverse development paths, of which examination demanded multi-causal and multi-directional approach advanced by Elias, Dunning and Maguire. The reasons for not having significant football business in these countries and being at the periphery of the global football figuration are manifold. In spite of being peripheral, both countries have been increasingly integrated into the global football figuration.

\section{Conclusion}

This study set out to answer three research questions. First, the characteristics and processes of the global football figuration were discussed, drawing on the works of 
prominent figurational sociologists such as Dunning, Maguire and Clark. A figurational approach synthesized with the concept of duality of glocality was advanced, which enabled the discussion of the global football figuration. The actors and processes comprising this figuration cannot be separated; they form networks of interdependencies together. The theoretical framework constructed this way not only considers figurations as the basic entities to be analysed and concentrates on power relations marked by interdependencies, but also further highlights the relevance of both homogenization and heterogenization processes, and thus the dynamic interchanges between the local and the global fields in football. For instance, increasing flow of sport broadcasting from the core to the periphery is linked to the processes of neoliberalism and demonstrates the growing significance of the core. However, the periphery interprets the programmes locally via own television studios and commentators. This framework assisted in answering the remaining two research questions and may be a useful tool for analysing the development of sports in different countries as well.

Second, the concept of periphery football country was discussed. Instead of strict conceptualization of periphery football, the analysis of countries' diverse development paths is suggested. It has been argued, that a country being peripheral with respect to football is not in a static state but rather characterized by continuous processes of shifts of power, which is a function of core-periphery interdependency ties. Furthermore, no country can be considered homogenous in terms of being peripheral; there are varied interdependencies and power struggles within countries. By way of illustration, Hungary has been characterized by a powerful core-periphery asymmetry during state socialism with its dominant capital, Budapest. Nevertheless, the power balance in football has started to shift slowly towards regional towns such as Debrecen and Gyor, when the political system's grip began to ease. Success seems to be a 
reasonable indicator of a country belonging to core, semi-periphery or periphery countries of football; nevertheless, further empirical research of economic, social, cultural and political processes behind the sport results is recommended to explore the antecedents of becoming a periphery country.

Third, based on the arguments provided for the first two research questions, this article made an attempt to explain why Finland and Hungary can be considered as periphery football countries. Applying a multi-directional approach, the development of Finnish and Hungarian football was analysed and compared from a figurational sociological stance, including economic environment, social meanings and cultural practices. It has been emphasized that the football domains of these countries have been involved in different types of power struggles and interdependency ties; their paths of development seem to be remarkably diverse, marked by both homogenization and heterogenization processes. Football's interpretation and tradition are fairly different in Finland and Hungary. For example, football in Hungarian state socialism was controlled by the state and financed centrally, which resulted in considerable international success. Subsequently the end of state support demolished football's economic base. At the same time, it has been clearly the major sport in the figuration of Hungarian sports.

Meanwhile, Finnish football has been characterized by a strong dependence on volunteers, which hindered the development of professional sports and caused the lack of achievements on the international level. Moreover, within the figuration of Finnish sports, football has been a significant but not the major sport.

This study has shown that that at present, both Finland and Hungary are peripheral football countries. However, by the 2000s, these countries form an organic part of the global football figuration through peripheral inclusion with migrating professional players and clubs increasingly operating as companies according to 
international standards. Nevertheless, neither of them has considerable football business and the national leagues serve as player suppliers to higher level leagues. Moreover, this paper has provided additional evidence with respect to the applicability of figurational sociology to the evolution of professional sports and globalization and sport.

Further research in this field would be of great help in gaining a deeper understanding on the development of football in these peripheral football countries. Case studies examining the changes in clubs' social networks, organizational changes, access to resources, embeddedness in their local environment and the influence of politics on football clubs are recommended topics.

\section{Funding}

This work was funded by the Faculty of Sport and Health Sciences of the University of Jyväskylä.

\section{Notes}

1. Giulianotti, Football: A Sociology of the Global Game, xi; Giulianotti and Robertson, Globalization and Sport, 60; Giulianotti and Robertson, Globalization \& Football, xiv; Itkonen and Nevala, 'Jalkapallo, maailma ja Suomi', 18; Maguire, Global Sport, 40. 2. Maguire, Global sport, 89.

3. Dunning, Sport matters; Bourke, 'Women's football in the Republic of Ireland', 175.

4. Globalization \& Football; xvi, 199 p; Giulianotti and Robertson, 'Globalization, football and transnationalism'; Krausz, 'A magyar futball "szetglobalizalasa"'; Giulianotti, Football: A Sociology of the Global Game.

5. Szabados, 'Labdarugoklubok strategiai', 60.

6. Bandyopadhyay and Mallick, Fringe Nations, 1.

7. Molnar, 'The Structural Changes of the Hungarian Sport life', 3; Itkonen and Nevala, 'Jalkapallo, tulevaisuus, tutkimus', 244; Dóczi, 'Sport and National Identity', 166.

8. See the works of these authors in the bibliography.

9. Giulianotti and Robertson, 'Globalization, Football and Transnationalism', 169. 
10. Maguire, Global Sport, 5; Murphy, Sheard and Waddington, 'Figurational Sociology and its Application to Sport', 95.

11. Elias, 'Essay on Sport and Violence', 154; Dunning, 'Dynamics of Modern Sports', 207.

12. Dunning, 'Civilizing sports', 17.

13. Bourke, 'Women's Football in the Republic of Ireland', 175; Maguire, Global Sport, 89.

14. Elias, 'Essay on Sport and Violence', 155.

15. Maguire, Global Sport, 5.

16. Dunning, Sport Matters, 126; Bourke, 'Women's Football in the Republic of Ireland', 175.

17. 'The Phenomenon of Norbert Elias', 117.

18. Dunning, Sport Matters, 19.

19. Eliasson, 'European football market', 387.

20. Giulianotti and Robertson, Globalization and Sport, 60; Globalization \& Football, 47.

21. Cowen, Creative Destruction, 16.

22. Maguire, Global Sport, 85.

23. Darby, Africa, football and FIFA, 2, 168.

24. Maguire, Global Sport, 38.

25. Darby, Africa, Football and FIFA, 163.

26. Dunning, Sport Matters, 125.

27. Itkonen and Nevala, 'Jalkapallo, tulevaisuus, tutkimus', 245.

28. Andrews and Ritzer, 'Grobal in the Sporting Glocal', 33.

29. Malcolm, 'Football Business and Football Communities', 102.

30. Dunning, Sport Matters, 127.

31. Malcolm, 'Football Business and Football Communities', 102.

32. Krausz, 'A Magyar Futball "Szetglobalizalasa"' 16; Deloitte, 'Football money league', 3.

33. Lechner, 'World-System Theory'.

34. Giulianotti and Robertson, Globalization \& Football, xiv; Nederveen Pieterse,

Globalization and culture, 12; Eliasson, 'European Football Market', 387.

35. Malcolm, 'Football Business and Football Communities', 103; Deloitte, 'Football Money League', 5.

36. Malcolm, 'Football Business and Football Communities', 103.

37. Dunning, 'Civilizing Sports', 17.

38. Giulianotti, Football: A Sociology of the Global Game, 24.

39. Giulianotti and Robertson, Globalization \& Football, 135; Giulianotti and Robertson,

'Globalization, Football and Transnationalism', 171.

40. Itkonen and Nevala, 'Popular game in Father Christmas Land?', 576.

41. Eliasson, 'European Football Market', 387. 
42. Giulianotti and Robertson, 'Globalization, Football and Transnationalism, 171.

43. Krausz, 'A Magyar Futball "Szetglobalizalasa'", 23.

44. Giulianotti and Robertson, Globalization \& Football, 32.

45. Maguire, Power and Global Sport, 24; Ram, 'Glocommodification', 11.

46. Giulianotti and Robertson, Globalization \& Football, 49.

47. Clarke, 'Figuring a Brighter Future', 204; Dunning, Sport Matters, 126; Bourke, 'Women's Football in the Republic of Ireland', 176; Giulianotti and Robertson, 'Globalization, Football and Transnationalism', 169.

48. Social Science Dictionary, 'Periphery Countries'.

49. Bandyopadhyay and Mallick, Fringe Nations, 1; Darby, Africa, Football, and FIFA, 165.

50. Elias, 'Essay on Sport and Violence', 156.

51. Eliasson, 'European Football Market', 387.

52. Krausz, 'A magyar futball "szetglobalizalasa"', 18.

53. Dunning, Malcolm and Waddington, 'Figurational Sociology and the Development of Modern Sport', 192.

54. Maguire, Global Sport, 49.

55. Maguire, Global Sport, 18.

56. Darby, Africa, Football and FIFA, 167.

57. Harvey, Rail and Thibault, 'Globalization and Sport', 264.

58. Darby, Africa, Football and FIFA, 173.

59. Maguire, Global Sport: Identities, Societies, Civilizations, 91.

60. Giulianotti and Robertson, Globalization \& Football, 40.

61. Maguire, Global Sport, 90.

62. Kuper and Szymanski, Soccernomics, 36.

63. Schneider, 'Factors Governing Success in International Football', 7.

64. Lanfranchi and Taylor, Moving with the Ball, 225.

65. Pierpoint, 'Business Strategies for a New Football Economy', 30.

66. Dahlen, 'Press Coverage of Football matches between Norway and Denmark', 338.

67. Bandyopadhyay and Mallick, Fringe Nations, 1.

68. Bandyopadhyay and Mallick, Fringe Nations, 7.

69. Eliasson, 'European football market', 387, 395; Krausz, 'A magyar futball "szetglobalizalasa"' 17.

70. Giulianotti and Robertson, 'Globalization, Football and Transnationalism', 171; Krausz, 'A Magyar Futball "Szetglobalizalasa"', 17.

71. Schiller, Communication and Cultural Domination; Giulianotti and Robertson,

Globalization \& Football, 39. 
72. Maguire, Global Sport, 93.

73. Giulianotti and Robertson, Globalization \& Football, 40.

74. Darby, Africa, Football, and FIFA, 163.

75. Maguire, Global Sport, 13; Eliasson, 'European Football Market', 386.

76. Eliasson, 'European Football Market', 397.

77. Featherstone, Undoing Culture, 110.

78. World Bank, 'GDP per capita, PPP'.

79. Poli, Besson and Ravenel, 'Demographic Polarisation of European Football'.

80. Itkonen and Nevala, 'Jalkapallo, maailma ja Suomi', 14.

81. Itkonen and Nevala, 'Popular Game in Father Christmas Land?', 579.

82. Kortelainen, 'Jalkapallo-Suomen maantiede', 81.

83. Itkonen and Nevala, 'Jalkapallo, maailma ja Suomi', 20.

84. Helsingin Sanomat, 'Veikkausliigaseurojen budjetit kaudella' 2012.

85. Dunning, Sport Matters, 115.

86. Szerovay, 'On the Way to Professionalism'.

87. Kozma and Nagy, Nagy penz - kis foci, 6.

88. Dunning, Sport Matters, 115.

89. Molnar, 'Hungarian Football', 306.

90. Hadas, 'Football and Social Identity', 58.

91. Hadas, 'Football and Social Identity', 61.

92. Kozma and Nagy, Nagy Penz - kis Foci, 5.

93. Krausz, 'A Magyar futball "szetglobalizalasa"', 15.

94. Geza Roka, club director of Debreceni VSC, in discussion with the author, 3 April 2013.

95. Geza Roka, club director of Debreceni VSC, in discussion with the author, 3 April 2013.

96. Molnar, 'The Structural Changes of the Hungarian Sport Life', 72.

97. Kozma and Nagy, Nagy Penz - kis Foci, 2.

98. Geza Roka, club director of Debreceni VSC, in discussion with the author, 3 April 2013;

Krausz, 'A Magyar futball "szetglobalizalasa"', 13.

99. Kortelainen, 'Jalkapallo-Suomen maantiede', 72.

100. Itkonen and Nevala, 'Popular Game in Father Christmas Land?', 572.

101. Itkonen, 'Jalkapalloilu paikallisena luokka- ja lajikamppailuna', 109.

102. Itkonen and Nevala, 'Jalkapallo, maailma ja Suomi', 13.

103. Itkonen and Nevala, 'Jalkapallo, maailma ja Suomi', 14.

104. Itkonen and Nevala, 'Jalkapallo, maailma ja Suomi', 20.

105. Villgren, 'Majoukkueen kannattajat', 164.

106. Molnar, 'Hungarian Football', 313. 
107. Hadas, Football and Social Identity: The Case of Hungary in the Twentieth Century, 52.

108. Molnar, Hungarian Football: A Socio-Historical Overview, 304.

109. Dóczi, 'Sport and National Identity', 167.

110. Molnar, 'Hungarian Football', 307.

111. Molnar, 'The Structural Changes of the Hungarian Sport Life', 72.

112. Molnar, 'Mapping Migrations', 464.

113. Dóczi, 'Sport and National Identity', 169.

114. Foldesi, Jakabhazy, and Nagy, 'Hungarian Sport'; Dóczi, 'Sport and National Identity', 178.

115. Itkonen and Nevala, 'Jalkapallo, maailma ja Suomi', 19.

116. Itkonen and Nevala, 'Popular Game in Father Christmas Land?', 580.

117. Itkonen and Nevala, 'Popular Game in Father Christmas Land?', 577.

118. Molnar, 'The Structural Changes of the Hungarian Sport Life', 76.

119. Molnar, 'Hungarian Football', 305.

120. Geza Roka, club director of Debreceni VSC, in discussion with the author, 3 April 2013.

\section{References}

Andrews, David L., and George Ritzer. 'The Grobal in the Sporting Glocal'. In Globalization and Sport, edited by Giulianotti, Richard and Roland Robertson, 2845. Malden: Blackwell Publishing, 2007.

Bandyopadhyay, Kausik, and Sabyasachi Mallick. Fringe Nations in World Soccer. Sport in the Global Society. Abingdon: Routledge, 2008.

Bauman, Zygmunt. 'The Phenomenon of Norbert Elias'. Sociology 13, (1977): 117-135.

Bourke, Ann. 'Women's Football in the Republic of Ireland: Past Events and Future Prospects'. Soccer \& Society 4, no. 2 (Summer, 2003): 162-181.

Clarke, Alan. 'Figuring a Brighter Future'. In Sport and Leisure in the Civilizing Process, edited by Dunning, Eric and Chris Rojek, 201-220. Basingstoke: Macmillan, 1992.

Cowen, Tyler. Creative Destruction : How Globalization is Changing the World's Cultures. Princeton (N.J.): Princeton University Press, 2002.

Dahlen, Peter. 'The 'Nordic Latinos' Meet the 'Mountain Primates': The Press Coverage of Football Matches between Norway and Denmark, 2002 and 2003'. Soccer \& Society 10, no. 3 (05, 2009): 341-357. 
Darby, Paul. Africa, Football, and FIFA: Politics, Colonialism, and Resistance. Sport in the Global Society. London: F. Cass, 2002.

Deloitte. 'Captains of Industry : Football Money League'. http://www.deloitte.com/assets/DcomUnitedKingdom/Local\%20Assets/Documents/Industries/Sports\%20Business\%20G roup/uk-sbg-football-money-league-2013.pdf (accessed March 14, 2013).

Dóczi, Tamás. 'Gold Fever(?): Sport and National Identity - the Hungarian Case'. International Review for the Sociology of Sport 47, no. 2 (2012): 165-182.

Dunning, Eric. 'Civilizing Sports : Figurational Sociology and the Sociology of Sport'. In Sociology of Sport and Social Theory, edited by Smith, Earl, 15-26. Leeds: Human Kinetics, 2010.

. 'The Dynamics of Modern Sports : Notes on Achievement - Striving and the Social Significance of Sport'. In Quest for Excitement: Sport and Leisure in the Civilizing Process, edited by Elias, Norbert and Eric Dunning, 205-223. New York: Basil Blackwell, 1986.

- Sport Matters : Sociological Studies of Sport, Violence, and Civilization. London: Routledge, 1999.

Dunning, Eric, Dominic Malcolm, and Ivan Waddington. 'Conclusion: Figurational Sociology and the Development of Modern Sport'. In Sport Histories: Figurational Studies of the Development of Modern Sports, edited by Dunning, Eric, Dominic Malcolm and Ivan Waddington, 191-206. London: Routledge, 2004.

Elias, Norbert. 'An Essay on Sport and Violence'. In Quest for Excitement: Sport and Leisure in the Civilizing Process, edited by Elias, Norbert and Eric Dunning, 150174. New York: Basil Blackwell, 1986.

Eliasson, Annika. 'The European Football Market, Globalization and Mobility among Players'. Soccer \& Society 10, no. 3 (05, 2009): 386-397.

Featherstone, Mike. Undoing Culture: Globalization, Postmodernism and Identity. Theory, Culture \& Society. London: SAGE, 1995.

Foldesi, S.,G., L. Jakabhazy, and J. Nagy. 'Post-Transformational Trends in Hungarian Sport (1995-2004)'. European Journal for Sport and Society 2, no. 2 (2005): 8596.

Giulianotti, Richard. Football: A Sociology of the Global Game. Cambridge: Polity Press, 1999.

Giulianotti, Richard and Roland Robertson. Globalization \& Football. Theory, Culture \& Society. Los Angeles: SAGE, 2009. 
. 'Recovering the Social: Globalization, Football and Transnationalism'. In Globalization and Sport, edited by Giulianotti, Richard and Roland Robertson, 5878. Malden: Blackwell Publishing, $2007 \mathrm{~b}$.

Hadas, Miklós. 'Football and Social Identity : The Case of Hungary in the Twentieth Century'. The Sports Historian 20, no. 2 (2000): 43-66.

Harvey, Jean, Geneviève Rail, and Lucie Thibault. 'Globalization and Sport: Sketching a Theoretical model for Empirical Analyses'. Journal of Sport \& Social Sciences 20, no. 3 (1996): 258-277.

Helsingin Sanomat. 'Veikkausliigaseurojen budjetit kaudella 2012'. http://www.hs.fi/urheilu/a1305559756479 (Accessed April 16, 2014).

Itkonen, Hannu. 'Jalkapalloilu paikallisena luokka- ja lajikamppailuna [Football as a Local Class and Sport Struggle]'. In Kuningaspelin kentät: Jalkapalloilu paikallisena ja globaalina ilmiönä [Fields of the King Game: Football as a Local and a Global Phenomenon], edited by Itkonen, Hannu and Arto Nevala, 100-114. Helsinki: Gaudeamus, 2007.

Itkonen, Hannu, and Arto Nevala. 'Jalkapallo, maailma ja Suomi [Football, World and Finland]'. In Kuningaspelin kentät: Jalkapalloilu paikallisena ja globaalina ilmiönä [Fields of the King Game: Football as a Local and a Global Phenomenon], edited by Itkonen, Hannu and Arto Nevala, 11-20. Helsinki: Gaudeamus, 2007a.

'Jalkapallo, tulevaisuus, tutkimus [Football, Future, Research]'. In Kuningaspelin kentät: Jalkapalloilu paikallisena ja globaalina ilmiönä [Fields of the King Game: Football as a Local and a Global Phenomenon], edited by Itkonen, Hannu and Arto Nevala, 241-248. Helsinki: Gaudeamus, $2007 \mathrm{~b}$.

'A Popular Game in Father Christmas Land? Football in Finland'. Soccer \& Society 13 , no. 4 (07, 2012): 570-583.

Kortelainen, Jarmo. 'Jalkapallo-Suomen maantiede [The Geography of Football in Finland]'. In Kuningaspelin kentät: Jalkapalloilu paikallisena ja globaalina ilmiönä [Fields of the King Game: Football as a Local and a Global Phenomenon], edited by Itkonen, Hannu and Arto Nevala, 71-83. Helsinki: Gaudeamus, 2007.

Kozma, Miklos, and Tamas Nagy. Nagy penz - kis foci avagy a paradigmavaltas lehetosege a magyar labdarugasban [Big Money - Small Football or the Chance to Shift of Paradigm in Hungarian Football]. Budapest: University of Economics and Public Administration, 2002.

Krausz, Tamas. 'Bevezetes: A magyar futball "szetglobalizalasa" [The "Overglobalization" of Hungarian Football]'. In A jatek hatalma: Futball - penz politika [The Power of the Game: Football - Money - Politics], edited by Krausz, Tamas and Miklos Mitrovits, 11-28. Budapest: L'Harmattan Kiado, 2008.

Kuper, Simon and Stefan Szymanski. Soccernomics. New York: Nation Books, 2009. 
Lanfranchi, Pierre, and Matthew Taylor. Moving with the Ball: The Migration of Professional Footballers. Oxford: Berg, 2001.

Lechner, Frank. 'World-System Theory'. http://www.sociology.emory.edu/globalization/theories01.html (accessed October 20, 2011).

Maguire, Joseph A. Global Sport: Identities, Societies, Civilizations. Reprinted 2001. ed. Cambridge, UK: Polity Press, 2001.

Power and Global Sport: Zones of Prestige, Emulation, and Resistance. London: Routledge, 2005.

Malcolm, D. 'Football Business and Football Communities in the Twenty-First Century'. Soccer \& Society 1, no. 3 (Autumn, 2000): 102-113.

Molnar, Gyozo. 'Globalization: The Structural Changes of the Hungarian Sport Life After the Communist Regime', 2002.

—. 'Hungarian Football: A Socio-Historical Overview'. Sport in History 27, no. 2 (08, 2007): 293-317.

'Mapping Migrations: Hungary Related Migrations of Professional footballers After the Collapse of Communism'. Soccer and Society 7, no. 4 (2006): 463-485.

Murphy, Patrick, Ken Sheard, and Ivan Waddington. 'Figurational Sociology and its Application to Sport'. In Handbook of Sports Studies, edited by Coakley, Jay and Eric Dunning, 93-107: SAGE, 2000.

Nederveen Pieterse, Jan. Globalization and Culture: Global Melange. 2nd ed. Lanham, Md: Rowman \& Littlefield, 2009.

Pierpoint, B. "Heads Above Water': Business Strategies for a New Football Economy'. Soccer \& Society 1, no. 1 (Spring, 2000): 29-38.

Poli, Raffaele, Roger Besson, and Loïc Ravenel. 'The Demographic Polarisation of European Football'. http://footballperspectives.org/demographic-polarisationeuropean-football (accessed March 30, 2013).

Ram, Uri. 'Glocommodification: How the Global Consumes the Local - McDonald's in Israel'. Current Sociology 52, no. 1 (2004): 11-31.

Schiller, H., I. Communication and Cultural Domination. Armonk, NY: M.E. Sharpe, 1976.

Schneider, M. "Factors Governing Success in International Football: Tradition, Wealth and Size - Or is there More to it?" FIFA Magazine (August 1996): 7-11. 
Social Science Dictionary. 'Periphery Countries'.

http://sociology.socialsciencedictionary.com/Sociology-

Dictionary/PERIPHERY_COUNTRIES (accessed November 20, 2011).

Szabados, Gabor. 'A labdarugoklubok strategiai [Srategies of the Football Clubs]'. In $A$ jatek hatalma: Futball - penz - politika [The Power of the Game: Football - Money - Politics], edited by Krausz, Tamas and Miklos Mitrovits, 58-77. Budapest:

L'Harmattan Kiado, 2008.

Szerovay, Mihaly. 'On the Way to Professionalism : JJK's Route to Veikkausliiga'. Lecture, University of Jyväskylä, Jyväskylä, 2011.

Villgren, Matti. 'Majoukkueen kannattajat identiteettinsä rakentajana [How the Fans of the Finnish National Team Build up Their Identities]'. In Kuningaspelin kentät: Jalkapalloilu paikallisena ja globaalina ilmiönä [Fields of the King Game:

Football as a Local and a Global Phenomenon], edited by Itkonen, Hannu and Arto Nevala, 155-165. Helsinki: Gaudeamus, 2007.

World Bank. 'GDP per capita, PPP'. http://data.worldbank.org/indicator/NY.GDP.PCAP.PP.CD (accessed November 12, 2014). 